The Quarterly Journal of Austrian Economics

Volume 23 | NO.3-4 | 265-280 | Fall/Winter 2020 WWW.QJAE.ORG

\title{
TuRning THE Word Upside Down: How CANTILLON Redefined THE ENTREPRENEUR
}

\author{
MARK THORNTON*
}

JEL Classification: B11, B31, B41, D81, L24, L26

АвsтRAст: The word entrepreneur originally meant someone who is active, risky, and even violent. In the sixteenth and seventeenth centuries it was used to denote a contractor who built large structures and fortifications for the government or provided supplies for the military for a contracted price but largely uncertain future costs. In contrast, Cantillon (1755) defined the entrepreneur as someone buying goods and resources at current market prices to be sold in the future at uncertain prices. His definition was adopted by the leading French economists of the time, and as a result it eventually became the common usage of the term, as will be seen in a sample of French dictionaries over time. In this remarkable and largely unrecognized transformation, Cantillon essentially turned the word upside down. Cantillon's entrepreneur was self-regulating on the basis of profit and loss, and thus became the foundation on which he was able to construct theories and models of the market economy, which we know as economic theory. His definition is essentially that of Frank Knight and Ludwig von Mises, so it has important implications for the development of the Chicago and Austrian schools of economics.

\section{INTRODUCTION}

\section{A central question regarding the concept of entrepreneurship $\mathcal{A}_{\text {in both the academic literature and public discourse remains }}$}

\footnotetext{
* Dr. Mark Thornton (mthornton@mises.org) is senior fellow at the Mises Institute and serves as the book review editor of the Quarterly Journal of Austrian Economics. 
the meaning of the term. It is now generally accepted that Richard Cantillon (1680-1743) first introduced the entrepreneur into the economics literature. Since that time the meaning of the term has undergone many changes and the list of duties, roles, and traits of the entrepreneur has grown ever longer. There are even archetypal forms, such as the grand Schumpeterian entrepreneur and the everelusive Kirznerian entrepreneur. However, the most important and dramatic change in the meaning of entrepreneur occurred nearly three centuries ago.

This is when, circa 1730, Cantillon is said to have first introduced the term. However, before that time, the word entrepreneur existed and had very different meanings. Most prominently it referred to someone who worked for the government as a private contractor. This government contractor, or what we might call a political entrepreneur, ${ }^{1}$ would typically bid on building a structure for the government and would thus have predetermined revenues, but uncertain future costs. Cantillon redefined the entrepreneur to be any individual who bought goods or resources at current market prices to be sold in the future at uncertain prices. So, his meaning switched the term from a political to a market orientation. It should be noted that Cantillon had extensive experience as both a government contractor, or political entrepreneur, and as a market entrepreneur.

Cantillon's new meaning turned the concept of the entrepreneur upside down. The focus shifted dramatically from the public sector to the private sector. The functional concepts of the nature and sources of uncertainty are now their opposites. From being few in number, entrepreneurs are now ubiquitous in society. The customer, formerly the government, is now the general public, including the government. Most importantly, the government's various problems with contract bidding and management are now largely swept away by the invisible hand of competitive markets.

Turning the concept of the entrepreneur upside down created what has become the most generally accepted meaning of the term: someone in private business, trading in the marketplace, and

\footnotetext{
${ }^{1}$ A political entrepreneur is someone in business who seeks to profit from government contracts, subsidies, and various forms of protectionism, such as tariffs, through political influence. It is a necessary aspect of corporate welfare, or what is now referred to as cronyism.
} 
uncertain of profit or loss. In doing so, Cantillon took an ordinary noun, redefined it, and created a theoretical concept that is still very much in use today. More than just a term, Cantillon's entrepreneur provides the conceptual mechanism that automatically regulates market behavior and thereby provides the foundation for the theoretical constructions presented in his book, Essai sur la nature du commerce en général (circa 1730, published in 1755), which in turn became the foundation of theoretical economics. ${ }^{2}$

It is now well established in the economics and entrepreneurship literatures that Cantillon was the first to introduce the term entrepreneur as a functional economic concept. The word had previously existed, but it had a different meaning. He radically transformed it. It will be shown that many of the economists who were directly or indirectly influenced by Cantillon adopted his conception and helped disseminate the new meaning. A sample of French dictionaries will be reviewed to demonstrate the change in meaning and the timing of that change, which later became the commonly accepted definition.

The second section chronicles the evolution of the word entrepreneur, while the third section traces these developments in French dictionaries. The fourth section explains that the adoption of Cantillon's concept by leading French economists, even prior to the publication of his Essai in 1755, helped spread the new meaning, eventually, into common usage. The fifth section concludes.

\section{II.THE EVOLUTION OF THE TERM ENTREPRENEUR}

According to Redlich $(1949,1)$, the term entrepreneur evolved from the French word entreprendre, which refers to someone who undertakes an activity, is active, or gets things done. According to Hoselitz $(1951,235)$, by the sixteenth century the term was used to refer to people who were engaged in "some violent warlike action." By the seventeenth century the term was used more generally to refer to people who take on risk-not merchants and manufacturers, but contractors who build large infrastructure projects for the

\footnotetext{
${ }^{2}$ See Brown and Thornton (2013) for examples of why entrepreneurship is essential for economic theory.
} 
government or the church, or who provide supplies to the military. Thus, the entrepreneur of this time was a military or government contractor-entrepreneur, or a political entrepreneur who works for a contracted price. Hoselitz (1951) also notes that in the legal literature of this period the entrepreneur is a government or military contractor. He also points out that the term was sometimes used to refer to explorers and colonizers, where the "violent warlike action" concept is combined with the government contractor concept. So, the original conception was largely political.

According to Hébert and Link $(1988,16)$ the classic case of the government contractor-entrepreneur is the tax farmer. On the one hand, the tax farmer is more like an entrepreneur, in the modern sense, than a government contractor, because he is someone who bids on the right to collect taxes in a certain jurisdiction for a given period of time, for a fixed fee, but is uncertain how much he can collect. A profit occurs if tax collections exceeded the amount of the bid. On the other hand, the tax farmer is more like a government contractor than a market entrepreneur, because the incentives of this ancient system often led tax farmers to be corrupt and to abuse taxpayers in various ways, such as undervaluing the goods collected as tax payments. This was the shame of Matthew, the tax farmer-turned-apostle of Jesus.

The ultimate statement of the entrepreneur as government contractor occurred in Bernard F. de Bélidor's La science des ingénieurs (1729). Bélidor was a prominent French engineer and his book was a leading textbook for engineers. He was elected a fellow of the Royal Society in 1726. Later he would be the first person to use integral calculus for solving the technical problems of hydraulics. A street in Paris was named after him in the nineteenth century. According to Bélidor, in contrast to Cantillon's market entrepreneur who is self-regulating due to the system of profit and loss, the government contractor-entrepreneur is devious and undependable and must be subject to government oversight and regulation. ${ }^{3}$

Hoselitz $(1951,240)$ finds that Bélidor's view of the entrepreneur was the "exact counterpart" to Cantillon's entrepreneur in that the former's entrepreneur is a government contractor who sells at a

\footnotetext{
${ }^{3}$ See Gupta et al. (2001) on the corrupt nature of political entrepreneurs.
} 
contracted price but has uncertain input prices in the future, while Cantillon's buys inputs at market prices and sells goods at uncertain prices in the future. Technically, both types of entrepreneurs risk losses, but more importantly, the nature of their risk is different and their incentives and behavior differ as well. Ekelund and Price $(2012,54)$ concluded that the different approaches resulted in "two different types of competition." According to Bélidor, the government contractor is always cutting corners and undermining quality and safety to cut costs in an effort to make a profit, whereas the market entrepreneur has to be more concerned about quality, safety, and reputation, i.e., long-run profit maximization. The critical difference is that Bélidor's political entrepreneur is likely undependable and in need of oversight, while Cantillon's entrepreneur is more dependable and self-regulating, and therefore can serve as a capable basis for economic theory and a self-regulating market economy. The concept of a self-regulating economy was largely unknown prior to Cantillon.

Bélidor's book was published in Paris in 1729 just prior to when scholars believe Cantillon was writing and finishing his own manuscript. Murphy $(1986,246)$ presents evidence which suggests that the manuscript was being written from 1730-31 and was completed sometime before Cantillon's death in 1734. There is no evidence that Cantillon knew or read Bélidor, but based on the contents of the Essai we can say that he was widely read in scientific matters. The men were contemporaries, and both were minor celebrities of the time. As a former government contractor, as well as a banker and investor in real estate, the widely read Cantillon would have been interested in the contents of Bélidor's book. Therefore, we cannot discount the possibility that Cantillon was aware of and possibly read it.

Bélidor's book would have been a sharp point of departure for Cantillon. Cantillon's ubiquitous entrepreneur would have contrasted sharply with Bélidor's conniving and untrustworthy government contractor-political entrepreneur. Conceivably, the text may have even provided some inspiration for Cantillon as a contrast for how he defined his entrepreneur. The most definitive consideration, however, is that the entrepreneur, as a government contractor, or political entrepreneur, was the well-established concept circa 1730. 


\section{REDEFINING THE ENTREPRENEUR}

The changing definition of entrepreneur, from the government contractor or political entrepreneur of Bélidor to the ubiquitous private sector entrepreneur, can be seen over time in French dictionaries. The sample of French dictionaries from the seventeenth to twentieth centuries, available online at the ARTFL Project of the University of Chicago, were consulted and translated for this purpose. ${ }^{4}$

According to Jean Nicot's dictionary, Thresor de la langue francaise: Tant ancienne que moderne (1606), the word entrepreneur referred to a susceptor or redemptor, with susceptor referring to a person who undertakes some role, especially the guardianship of another, while redemptor referred to someone who works as a contractor. This early seventeenth-century dictionary entry therefore provides the very general notion of any undertaking, including caretaking and contracting that benefits others.

At the end of the seventeenth century, the Dictionnaire de L'Académie française (first edition, 1694) indicates that the entrepreneur is someone who undertakes large construction projects for a specified price. Later, in the fourth edition (1762), the Dictionnaire defined the entrepreneur as a contractor who undertakes substantial projects, such as building fortifications, bridges, or paving city streets. The fifth edition (1798) and sixth edition (1832-35) describe the same thing, although the sixth gives an example of an entrepreneur in the production of textiles. Jean-Baptiste Say (1767-1832), who was long credited with introducing the term in this period, owned a textile factory. The eighth edition (1932-35) also broadened the definition to include contractors of all sorts. The Dictionnaire notes that when the term is used in the feminine it explicitly refers to a textile manufacturer. Hence, the term entrepreneur evolved from indicating someone who is very active to a government contractor or political entrepreneur, and then into the prototypical modern market entrepreneur over this period.

In Jean-François Féraud's Dictionnaire critique de la langue française (Marseille, 1787-88), the entrepreneur was not mentioned, but entreprenant (the adjective "enterprising" or the verb "undertaking")

$\overline{{ }^{4} \text { ARTFL Project, https://artfl-project.uchicago.edu/content/dictionnaires-dautrefois. }}$ 
was defined as bold business behavior. Émile Littré's Dictionnaire de la langue française (1872-77) also indicated that the term was used to denote a contractor or someone who undertakes a business project. Littré's Dictionnaire in particular referenced Étienne Bonnot de Condillac and Jean-Baptiste Say, whose work generalized and broadened the definition of the entrepreneur to include manufacturing, banking, farming, and trade, and even designated entrepreneur as a term from political economy.

This is important because, as Thornton (2009a) shows, Condillac $(1997,134 n)$ was heavily influenced by Cantillon. In a rare footnote, Condillac heaps high praise on Cantillon:

I have drawn the basis of this chapter from this work [Essai sur la nature $d u$ Commerce, Cantillon, 1755] and several observations of which I have made use in other chapters. It is one of the best works I know on this subject, but I am far from knowing them all.

Condillac follows Cantillon on many economic concepts and phenomena, but rarely excels beyond him. For example, on interest and usury he follows him quite closely only to admit, contra Cantillon, that some very high rate of interest, unspecified, might qualify as usury. The entrepreneur for Condillac is restricted to the commercial entrepreneur, farmers, and large undertakers of every kind, but he fails to extend the term to Cantillon's ubiquitous uncertainty bearer.

Thus, the definition of the entrepreneur changed from the imprecise meaning of a risky person in the sixteenth and seventeenth centuries to become a government contractor, or political entrepreneur, in the seventeenth and eighteenth centuries, before coming to represent any person engaged in some form of business activity after the late eighteenth and early nineteenth centuries. The actual evolution of the word is much more complicated and inexact. Hélène Vérin (1982) describes this complex historical evolution; however, when Vérin (2014) distills it into a comprehendible synopsis, a very similar story emerges.

The concept evolved alongside the progression from precapitalistic times toward the heyday of European colonialism and war, and toward the emergence of capitalism and the Industrial Revolution. The most basic change that occurred over this evolution is 
that the subject changed from a political entrepreneur to anyone who engages in a private business, including farming, manufacturing, and trade, in which there is uncertainty about future market prices. Landström (2010, 9-10) chronicles a comparable transformation of the English term undertaker along a similar timetable.

\section{HOW CANTILLON'S CONCEPTION SPREAD}

The evidence tracing the changing meaning of the entrepreneur does find Cantillon at the historical pivot prior to the new meaning gaining widespread acceptance and usage. The most knowledgeable scholar on the subject, Murphy $(1986,246)$ believes that Cantillon completed the Essai in manuscript form around 1730, although it was not published until 1755. So, how would the redefinition by an obscure anonymous writer spread to eventually become accepted usage?

The acceptance of Cantillon's concept of the entrepreneur was due to his influence on subsequent writers. Most notably, the popular writer Mirabeau the elder had a manuscript copy of the Essai for fourteen years prior to its publication in 1755. Likewise, the famous dictionary publisher Malachy Postlethwayt drew on the Essai both prior to and after it was published. Also, Murphy (1986, 308) shows that Vincent de Gournay, a leader of the Physiocrats, must have read it before it was published.

One of the first noteworthy uses of Cantillon's concept of the entrepreneur as the leader of a private business appears in the famous reference work of the period Diderot and d'Alembert's Encyclopédie, ou dictionnaire raisonné des sciences, des arts et des métiers, published from 1751 to 1772. In an article written by a leader of the Physiocrats, François Quesnay (Gendzier, ed. 1967, 814), on the topic of "grains" Cantillon's entrepreneur is interwoven with the social vision of the Physiocrats:

We do not now look upon the rich farmer as a worker who personally tills his land. He is an entrepreneur who administers and increases the value of his enterprise by his intelligence and wealth. Agriculture managed by rich cultivators is a very honest and lucrative profession, reserved for free men who are in a position to advance a considerable outlay of money required for the cultivation of the land that provides 
work for the peasants and always procures for them satisfactory and assured earnings. These are, in the opinion of M. de Sully, the true farmers or the true financiers whom we must create and support in a kingdom possessing enormous territory, because it is from their wealth that must arise the sustenance of the nation, public affluence, the revenues of the sovereign, those of landowners, of the clergy, great expenditures distributed to all the professions, a large population, and the power and prosperity of the state.

Quesnay was the leader of the Physiocrats and the school's chief theoretician. He described the farmer not as a field hand or supervisor, but rather as an "entrepreneur who governs and manages his enterprise by his intelligence and his wealth" (Gendzier ed. 1967, 814). Higgs $(1897,30-31)$ reminds us that Quesnay explicitly references Cantillon's "fundamental truths" in this article. Cantillon biographer Antoin Murphy $(1986,307-08)$ concludes that the group associated with Vincent de Gournay and Quesnay was responsible for the publication and promotion of Cantillon's Essai in 1755.

Condillac, whom Émile Littré's Dictionnaire de la langue française (1872-77) references on this topic, also viewed the farmer as an entrepreneur who oversaw cultivation and supervised those who carried out the work. Whereas previously farmers had not been thought of as entrepreneurs in any sense, now the entrepreneur was seen as being in "each profession," including farming and manufacturing. Condillac ([1997] 1776, 147) points out that all types of entrepreneurs conduct their business at risk of failure:

Indeed, an entrepreneur can only maintain his trade in so far as the money, with which he makes advances, comes back continuously to him with a return in which he finds his subsistence and that of the workers he employs, that is to say, a wage for them and a wage for him.

Condillac also examined factors that increase and decrease the number of entrepreneurs. His discussion occurred in a chapter on interest and usury, a placement that according to Redlich (1949, 6-7) was not common before or after this time. This placement also suggests the influence of Cantillon, who had a similar but longer treatment of this issue in his famous chapter on interest and usury in the Essai. As shown above, in a footnote in his own chapter Condillac (1776 [1997], 134) acknowledged that he was heavily influenced by Cantillon. 
Another significant economist with connections to Cantillon was Anne-Robert-Jacques Turgot. According to Hébert and Link (1988), Turgot referenced Cantillon and followed him on a large number of issues, but the strongest influence is indirect, from Quesnay, Gournay, and other Physiocrats. For example, in agriculture, manufacturing, and any other field of production Turgot, like Cantillon, said that there are two basic classes of producers in society: the entrepreneurs and the hired wage workers. Turgot's theory of entrepreneurship is often thought to be more advanced than, or at least different from, that of Cantillon (Rothbard 1995, 395) because the former's focus was on the more Schumpeterian leading capitalist-entrepreneurs while Cantillon's entrepreneur was ubiquitous in the marketplace.

The capitalist-entrepreneur must first accumulate saved capital in order to advance payments to laborers while the goods are being produced. Turgot pointed out that advances of capital are vital in all enterprises. It makes no difference whether such savings are supplied by someone else or by the entrepreneurs themselves. For example, in agriculture, capitalist-entrepreneurs must save funds to pay workers, buy cattle, and pay for buildings and equipment until their crops are harvested. Only after the harvest can they sell the crops and recoup their advances and possibly make a profit. The same process occurs in manufacturing and in every field of production. Entrepreneurs seek to gain profits and to avoid losses.

However, Brown and Thornton (2013) show that Cantillon did not ignore the capitalist-entrepreneur in the least. Indeed, the capitalist is completely integrated into Cantillon's theory of entrepreneurship. Either the entrepreneur provides his own resources or he borrows them, in which case the lender, not the banker, also becomes a kind of entrepreneur in Cantillon's approach because of the risks, not uncertainty, of return. The lender manages these risks by either requiring collateral, only dealing with known dependable borrowers, or in the case of high-risk borrowers by charging high rates of interest to a large number of such customers, so that by playing the percentages the lender is neither fully enriched or bankrupted by defaults. This fits perfectly well with the approach of Frank Knight and Ludwig von Mises. In the final analysis, 
Cantillon's entrepreneur includes the capitalist-entrepreneur. ${ }^{5}$ Turgot and Cantillon also share the insight that entrepreneurs will only invest in risky enterprises if they expect greater profits than the loan rate of interest. They both emphasized uncertainty as an important aspect of entrepreneurship. Therefore, Turgot, like Quesnay and Condillac, had many views in common with Cantillon, accepted many of his views on entrepreneurship, and subsequently helped disseminate Cantillon's basic definition of entrepreneurship, both through his own writings, textbooks, and through popular reference works.

Scholars, at least up through Cole (1942, 120), had long mistakenly thought that Jean-Baptiste Say introduced the term entrepreneur into economics. It was Schumpeter (1954, 222), writing that "nobody before Cantillon had formulated it so fully," who corrected the historical record when he found that Cantillon was the first to have a clear conception of the entrepreneur as one who makes purchases at current prices but sells in the future at uncertain prices, and who therefore risks losses in pursuit of profits.

According to Say $(1971,83)$, entrepreneurs use their "industry" to organize and direct the factors of production to achieve the "satisfaction of human wants." Instead of being merely managers, entrepreneurs are forecasters, project appraisers, and risk takers as well. Like Turgot, Say saw that entrepreneurs use their own financial capital or borrow it from others to advance funds toward labor, raw materials, and capital goods. Entrepreneurs only recoup these payments if they succeed in selling their products to buyers at prices that exceed costs.

For Say, entrepreneurial behavior embraces several kinds of economic activities, such as planning, organization, supervision, innovation, and the supply of capital. He therefore added various aspects of entrepreneurship to Cantillon's general theory. Say's approach is very modern in the sense that modern entrepreneurship scholars rely on both a general definition of the entrepreneur as an uncertainty bearer but are also very interested in the additional features, roles, and characteristics of entrepreneurs that contribute to their success or failure.

\footnotetext{
${ }^{5}$ Cantillon does hold that a penniless beggar is an entrepreneur, but this is not the resourceless Kirznerian entrepreneur, because the beggar must contribute his time to beg money and food.
} 
For example, Salerno $(2018,193)$ shows that Rothbard developed the concept of a "decision-making rent" as a return on a kind of labor performed by the entrepreneur as owner and ultimate decision-maker that could otherwise not be hired by the firm. This rent to the owner is separate from profit and loss. It is a function that is concerned with the "productive organization and technique, which is distinct from the function of forecasting uncertain future market conditions." Decision-making, however, is a necessary aspect of entrepreneurship, while many of the features of entrepreneurship studied by modern scholars are not necessary ones but are merely highly correlated with successful entrepreneurs.

Comparing the two approaches to entrepreneurship, Say provides a more elaborate description of what an entrepreneur does, similar to the modern understanding. However, this approach also deflects our attention from uncertainty bearing, and Hébert (1985) finds no evidence that Cantillon regarded any of these additional features as fundamental to the entrepreneur. Say also narrows the scope of entrepreneurship to manufacturing which was a common theme of the time due to the emergence of the Industrial Revolution.

Hoselitz (1951) finds that Say's theory of the entrepreneur cannot be tangibly connected with Cantillon's and concludes that Say's theory represented a retrogression from Cantillon and the Physiocrats. However, Schumpeter $(1954,222)$ draws our attention to a connection between Cantillon and Say: "Though there is nothing to show that he actually influenced J. B. Say, it is none the less true that 'objectively' his performance on this point... is the link between the two." Of course, we do know that Say was influenced by the Physiocrats and that the Physiocrats were heavily influenced by Cantillon. Additionally, as Salerno (1985) finds, Say was possibly influenced by Cantillon, particularly on methodology, and both Cantillon and Say modeled the economy as a mechanism regulated by entrepreneurship.

\section{CONCLUSION}

This historical theme of connections and influences is complex, but the main points seem clear: 1 . The original meaning of the word was different from modern usage and referred to government 
contractors or political entrepreneurs as late as 1729. 2. Cantillon used the term circa 1730 to refer to a market entrepreneur acting under uncertainty. 3 . French dictionaries chronicle the replacement of the original definition with Cantillon's over time. 4. Influential French economists spread Cantillon's new meaning and brought it into common usage. Most significant for our purposes here is that although Say had a more elaborate view of the entrepreneur than did Cantillon, the Dictionnaire quotes Say only on Cantillon's narrower view of the entrepreneur.

Cantillon redefined the entrepreneur, transforming him from a government contractor or political entrepreneur who works for a contract price and has uncertain future costs into a pervasive one who purchases inputs at market prices only to make sales in the future at uncertain market prices. The element of uncertainty creates the potential for profits and losses, great riches and bankruptcy. Cantillon used this conception of the role of the entrepreneur as uncertainty bearer to great effect in creating an economic theory of the market economy (Thornton 2007, 2009b, Brown and Thornton 2013). Economists such as Mirabeau, Quesnay, Condillac, Turgot, and others adopted Cantillon's concept to great effect, and by the time of Jean Baptiste Say, it was considered common usage and was employed without further attribution throughout the next century.

Establishing the core meaning of entrepreneurship as uncertainty bearing in the pursuit of profit as the commonly understood one does not mean that the theory of entrepreneurship has remained static. Indeed, Hébert and Link (1988) remind us that there were many twists and turns, redirections, dry holes, and elaborations during the interlude between Say and modern theories. When more modern economists examined the concept of entrepreneurship, they gravitated back toward Cantillon without knowing of his existence. Beginning with Hawley (1907) and Davenport (1913) and ending with Knight (1921) and Mises (1949), the core theory of the entrepreneur returned to its origins in Cantillon. In turn, the latter two economists became founders of the Chicago school and the modern Austrian school of economics, respectively.

Of course, since that time there have also been some big new ideas in entrepreneurship theory, including the grand Schumpeterian entrepreneur and the ever elusive Kirznerian entrepreneur, 
as well as what is analogous to a big bang in empirical entrepreneurship research and the establishment of entrepreneurship as a separate academic discipline. The core, however, remains in Cantillon's entrepreneur.

\section{REFERENCES}

Académie française. 1694, 1762, 1798, 1835, 1932-35. Dictionnaire de $l^{\prime}$ Académie française. $1^{\text {st }}, 4^{\text {th }}, 5^{\text {th }} 6^{\text {th }}, 8^{\text {th }}$ eds. ARTFL Project. https://artflproject.uchicago.edu/.

Bélidor, Bernard F. de. 1729. La science des ingénieurs dans la conduite des travaux de fortification et d'architecture civile. 2 vols. Paris: Claude Jombert.

Brown, Christopher, and Mark Thornton. 2013. "How Entrepreneurship Theory Created Economic Theory." Quarterly Journal of Austrian Economics 16, no. 4: 401-20.

Cantillon, Richard. [1755] 1931. Essai sur la nature du commerce en général, ed. and trans. Henry Higgs. London: Royal Economic Society. The 2010 English translation is available at: https://mises-media.s3.amazonaws. com/An Essay on Economic Theory_2.pdf.

Cole, Arthur H. 1942. "Entrepreneurship as an Area of Research." Journal of Economic History 2: 118-26.

Condillac, Étienne Bonnot de. [1776] 2008. Commerce and Government Considered in Their Mutual Relationship, trans. Shelagh Eltis. Indianapolis: Liberty Fund.

Davenport, Herbert J. 1913. The Economics of Enterprise. New York: Macmillan.

Diderot, Denis, and Jean Le Rond d'Alembert. 1751-72. Encyclopédie, ou dictionnaire raisonné des sciences, des arts et des métiers. Paris: Briasson, David, Le Breton, or Durand.

Ekelund, Robert B., Jr., and Edward O. Price III. 2012. The Economics of Edwin Chadwick: Incentives Matter. Northampton, Mass.: Edward Elgar Publishing, Inc.

Féraud, Jean-François. 1787-88. Dictionaire critique de la langue française. Marseille: Jean Mossy.

Gendzier, Stephen J., ed. and trans. 1967. Denis Diderot's The Encyclopedia: Selections. New York: Harper and Row. 
Gupta, Sanjeev, Luiz de Mello, and Raju Sharan. 2001. "Corruption and Military Spending." European Journal of Political Economy 17, no. 4: 749-77.

Hawley, Frederick B. [1907] 2018. Enterprise and the Productive Process: A Theory of Economic Productivity Presented from the Point of View of the Entrepreneur and Based Upon Definitions, Secured Through Deduction (and Presumably, Therefore, Precise and Final) of the Scope and Fundamental Terms of the Science of Economics. Pranava Books.

Hébert, Robert F. 1985. "Was Richard Cantillon an Austrian Economist?." Journal of Libertarian Studies 7, no. 2: 269-79.

Hébert, Robert, and Albert Link. 1988. The Entrepreneur: Mainstream Views and Radical Critiques. New York: Praeger.

Higgs, Henry. 1897. The Physiocrats: Six Lectures on the French Économistes of the $18^{\text {th }}$ Century. New York: The Macmillan Company.

Hoselitz, Bert F. [1951] 1960. “The Early History of Entrepreneurial Theory." In Essays in Economic Thought: Aristotle to Marshall, ed. Joseph J. Spengler and William R. Allen. Chicago: Rand McNally and Company.

Knight, Frank H. 1921. Risk, Uncertainty, and Profit. Boston and New York: Houghton Mifflin Co.

Landström, Hans. 2005. Pioneers in Entrepreneurship and Small Business Research. New York: Springer.

Littré, Émile. 1863-72. Dictionnaire de la langue française. Paris: Librairie Hachette et Cie.

Mises, Ludwig von. 1949. Human Action: A Treatise on Economics. New Haven, Conn.: Yale University Press.

Murphy, Antoin E. 1986. Richard Cantillon: Entrepreneur and Economist. Oxford: Clarendon.

Nicot, Jean. 1606. Thresor de la langue francoyse, tant ancienne que moderne. Paris: David Douceur.

Quesnay, François. [1757] 1967. "Grains" (abridged). Pp. 812-31 in The Encyclopedia: Selections, ed. Stephen J. Gendzier and trans. Denis Diderot. Vol. 7. New York: Harper and Row.

Redlich, Fritz. 1949. "The Origins of the Concepts of 'Entrepreneur' and 'Creative Entrepreneur."' Explorations in Entrepreneurial History 1: 1-7. 
Rothbard, Murray N. 1995. Economic Thought before Adam Smith: An Austrian Perspective on the History of Economic Thought, Volume 1. Cheltenham, U.K.: Edward Elgar Publishing, Ltd.

Salerno, Joseph T. 1985. "The Influence of Cantillon's Essai on the Methodology of J. B. Say." Journal of Libertarian Studies 7, no. 2: 305-16.

— 2018. "Are Ownership Rent and Pure Profit Separate Returns to the Entrepreneur?." Quarterly Journal of Austrian Economics 21, no. 3: 193-208.

Say, Jean-Baptiste. [1880] 1971. A Treatise on Political Economy or the Production, Distribution and Consumption of Wealth. Reprint, New York: Augustus M. Kelley.

Schumpeter, Joseph A. 1954. History of Economic Analysis. New York: Oxford University Press.

Thornton, Mark. 2007. "Richard Cantillon and the Discovery of Opportunity Cost." History of Political Economy 39, no. 1: 97-119.

- 2009a. "Cantillon and the Rise of Anti-Mercantilism." Procesos de mercado: revista europea de economía política 6: 13-42.

- 2009b. "Cantillon and the Invisible Hand." Quarterly Journal of Austrian Economics 12, no. 2: 27-46.

Vérin, Hélène. 1982. Entrepreneurs, entreprise: Histoire d'une idée. N.P.: Presses universitaires de France.

. [2004] 2014. Dictionary of Untranslatables: A Philosophical Lexicon, ed. Barbara Cassin, trans. ed. Emily Apter, Jacques Lezra, Michael Wood, and trans. Steven Randall et al. Princeton, N.J.: Princeton University Press. 